УДК 342.51

DOI https://doi.org/10.51989/NUL.2021.6.17

\title{
КОНТРОЛЬ ЯК ОСНОВНА ФУНКЦІЯ ОРГАНІВ ПУБЛІЧНОЇ АДМІНІСТРАЦІЇ УКРАЇНИ
}

\author{
Нестеренко Катерина Олександрівна, \\ кандидат юридичних наук, \\ доцент кафедри державно правових дисциплін \\ Криворізького навчально-наукового інституту \\ Донецького державного університету внутрішніх справ
}

\section{Камінський Павло Дмитрович,}

кандидат економічних наук, доцент кафедри державно правових дисциплін Криворізького навчально-наукового інституту Донецького державного університету внутрішніх справ

За сучасних умов розвитку та функціонування державності особливої уваги потребує питання модернізації публічного адміністрування, активізації ролі органів публічної адміністрації. Це зумовлює доцільність підвищення ефективності системи контролю за діяльністю зазначених органів, розроблення заходів щодо вдосконалення нормативно-правового поля здійснення державного й публічного контролю за публічним адмініструванням.

Проаналізовано змістове наповнення поняття «контрольна функція органів публічної адміністрації», яка $\epsilon$ різновидом функції соціального контролю, що являє собою систему перевірки уповноваженими суб'єктами (державні органи, громадськість) діяльності органів і посадових осіб органів публічного адміністрування, ефективного використання матеріальних і фінансових ресурсів задля ідентифікації порушень законодавчих норм і виявлення невідповідностей результатів поставленим завданням.

Визначено основні заходи оцінювання забезпечення ефективності контрольних заходів, що здійснюється за такими етапами: визначення кількісних і якісних параметрів оцінювання ефективності контролю; оцінка компетентності контрольних органів або оцінка результативності внутрішнього й зовнішнього контролю; розроблення заходів підвищення ефективності управлінських рішень при реалізації внутрішнього контролю в організації, установі тощо (характерним є для стадії попереднього контролю). Для оцінки ефективності контрольної функції органів публічної адміністрації запропоновано такі критерії: якість і повнота, достовірність інформації, що надходить до контролюючих органів; своєчасність контролю, регулярність контролю, об'єктивність контролю, необтяжливість заходів контрольного характеру, оперативність і публічність результатів контролю.

Ключові слова: контрольна функція, правова держава, публічна влада, публічна адміністрація, публічне управління, контрольна функція органів публічної адміністрації, адміністративне право, адміністративно-правові засади.

\section{Nesterenko Kateryna, Kamynskyi Pavlo. Control as the main function of public administration bodies of Ukraine}

Under modern conditions of development and functioning of statehood, the issue of modernization of public administration, intensification of the role of public administration bodies is gaining special attention. This determines the expediency of increasing the efficiency of the system of control over the activities of these bodies, the development of measures to improve the legal framework for state and public control over public administration.

The content of the concept of "control function of public administration bodies" is analyzed, which is a kind of function of social control, which is a system of inspection by authorized entities (state bodies, public) of bodies and officials of public administration bodies, efficient use of material and financial resources. to identify violations of legislation and identify inconsistencies in the results of the task.

The main measures of evaluation of the effectiveness of control measures are determined, which is carried out in the following stages: determination of quantitative and qualitative 
parameters of evaluation of control efficiency; assessment of the competence of control bodies or assessment of the effectiveness of internal and external control; development of measures to increase the effectiveness of management decisions in the implementation of internal control in the organization, institutions, etc. (characteristic of the stage of preliminary control) and to assess the effectiveness of the control function of public administration bodies, the following criteria are proposed: quality and completeness, reliability of information received by regulatory authorities; timeliness of control, regularity of control, objectivity of control, ease of control measures, efficiency and publicity of control results.

Key words: control function, rule of law, public authority, public administration, public administration, control function of public administration bodies, administrative law, administrative and legal principles.

Постановка проблеми. За сучасних умов розвитку й функціонування державності особливої уваги набуває питання модернізації публічного адміністрування, активізації ролі органів публічної адміністрації. Це зумовлює доцільність підвищення ефективності системи контролю за діяльністю зазначених органів, розроблення заходів щодо вдосконалення нормативно-правового поля здійснення державного та публічного контролю за публічним адмініструванням.

Стан дослідження. Дослідженню теоретичних і методологічних засад, організаційно-методичних заходів формування, удосконалення та посилення державного й публічного контролю в державі присвячено роботи багатьох відомих вітчизняних і зарубіжних науковців, серед яких В. Авер'янов, О. Андрійко, Ю. Барабаш, О. Батанов, Ю. Битяк, В. Гаращук, В. Колісник, Т. Коломоєць, С. Косінов, А. Крусян, П. Любченко, О. Марцеляк, П. Матвієнко, Т. Наливайко, О. Остапенко, О. Петришин, В. Серьогін, С. Серьогіна, О. Сушинський, В. Тацій, Ю. Тодика, В. Федоренко, В. Шаповал, Ю. Шемшученко та ін. Однак комплексні наукові дослідження, присвячені контрольній функції органів публічної адміністрації, практично відсутні. Отже, метою статті $€$ детальний аналіз контролю як основної функції органів публічної адміністрації.

Виклад основного матеріалу. В Україні контроль у різних його організаційних формах здійснює більшість державних і муніципальних органів і їх посадових осіб. Контроль $\epsilon$ одним з основних складників управлінського процесу, що $€$ елементом зворотного зв'язку, який сповіщає суб'єкту управління про результати його впливу на об'єкт. Результати роботи органів і посадових осіб публічної влади багато в чому залежать від належної організації та ефективності контролю.

Контроль за органами публічної влади в цілому й органами місцевого самоврядування зокрема $\epsilon$ різновидом соціального контролю, який покликаний забезпечувати збереження та розвиток соціальної системи, упорядковане функціонування її елементів. Соціальний контроль $\epsilon$ комплексом заходів, спрямованих на формування соціальної рівноваги як основи сучасного суспільного устрою та управління ним.

У науковій літературі він розглядається в широкому значенні як сукупність механізмів у соціальному просторі (окремих соціальних групуваннях, організаціях населення тощо), які забезпечують його самоорганізацію й самозбереження шляхом установлення та підтримки певного нормативного порядку й використання відповідних зразків поведінки, прикладами яких можуть слугувати моральні та культурні цінності певного соціуму, традиції, правові норми, що традиційно склалися, тощо. У вузькому значенні його розуміють як сукупність засобів і методів впливу суспільства на небажані форми девіантної поведінки з метою їх елімінування (усунення) або скорочення, мінімізації [1, с. 221].

Окремими дослідниками контроль визначається через системний підхід, що дає змогу розуміти контроль як комплекс заходів і процесів, що відбуваються в окремій соціальній організації та спрямовані на дотримання норм і правил цього інституту в тому числі в умовах обмежень функціонування системи. Так, В. Горшеньов та I. Шахов визначають соціальний контроль як окрему систему регуляторів функціонування соціальної організації, таких як інститути права, моралі, традицій тощо [2, с. 18]. 
Уважаємо, що протиставляти державний контроль соціальному немає підстав, державний і недержавний контроль у сукупності становить контроль соціальний. С. Косінов стверджує, що соціальний контроль $\epsilon$ складовою частиною більш загальної й різноманітної системи соціального регулювання поведінки людей і суспільного життя; здійснюється через внутрішні та зовнішні механізми взаємодії; передбачає соціальну взаємодію особистості й соціального контролю; його характер, зміст і спрямованість визначаються характером, природою, типом соціальної системи; підтримує порядок і стабільність у суспільстві, а також забезпечує соціальне відтворення (наступність) у напрямі, що відповідає визначеній стратегії розвитку [3, с. 24].

Виходячи 3 доктрини соціального управління, можемо зробити висновок, що контроль реалізується в розрізі таких напрямів:

- визначення меж прийнятної для суспільства поведінки окремого індивідуума;

- спрямування поведінки об'єктів у межах, які створюють оптимальну та прийнятну для суспільства поведінку;

- виявлення відхилень від заданих меж з метою вжиття заходів впливу [4, с. 50].

Доцільним, на наш погляд, єдослідження поняття «контроль» з позиції соціального управління, відповідно до якого контроль $\epsilon$ сукупністю процесів спостереження й аналізу відповідності діяльності об'єкта контролю визначеним управлінським підходам, а також виявлення відхилень від загальновстановлених принципів організації та регулювання [5, с. 240].

Контроль - важливий складник будьякої системи управління, що гарантує та забезпечує його якісне й ефективне здійснення. Ю. Битяк визначає контроль як частину (елемент) управління, сутність якого полягає у відстеженні ходу і стану діяльності підконтрольного об'єкта, спрямованого на створення систематичного огляду дотримання норм чинного законодавства країни, що реалізується через втручання органів контролю до діяльності підконтрольних об'єктів і проявляється як надання рекомендацій, застосування заходів впливу на управління, заходів примусу [6, с. 278].
Англійці використовують термін «контролінг» (англ. controlling) як систематичний контроль, відслідковування ходу реалізації завдань з одночасним унесенням коригувань подальшої роботи. Також широко застосовується термін «моніторинг», зміст якого $€$ практично ідентичним терміну «контролінг», лише 3 тією відмінністю, що до функцій моніторингу відносяться прогнозування й охорона власності. Термін «контроль» поступово поглинається термінами «моніторинг» або «контролінг» (хоча $\epsilon$ й інші точки зору, відповідно до яких останні два терміни $\epsilon$ складником контролю) [7, с. 426].

Окремим і поширеним поглядом на контроль, що переважає в науковій літературі, $\epsilon$ розгляд контролю як самостійної гілки влади. Уперше ще на початку XX століття таку думку висловив видатний китайський вчений Сунь Ят Сен. Тоді ж ним була сформульована «конституція п'яти гілок влади», у якій він виокремлював, окрім класичних («законодавчої», «виконавчої», «судової»), і самостійні: «екзаменаційну» та «контрольну» влади [7, с. 430].

Теорія поділу влади на чотири гілки - «законодавчу», «виконавчу», «судову» й «контрольну» - і сьогодні має багатьох прихильників. Більшість науковців визначає сутність контролю як функцію уповноважених суб'єктів, спрямовану на забезпечення додержання законності, як форму реалізації владних повноважень, як сукупність прийомів і способів, які можуть бути застосовані в процесі контрольної діяльності. В. Гаращук дотримується думки щодо самостійності контролю як окремої функції управління, яка допомагає в реалізації всіх інших функцій управління [7, с. 42].

Узагальнюючи запропоновані в науці концепції контрольної діяльності, фахівці виділяють три підходи до розкриття ії природи: контроль як органічна функція управління; контроль як набір засобів регулювання поведінки окремої особи або організації в цілому; контроль як обмежувальна функція організації упорядкованої діяльності, до завдань якої входить забезпечення нагляду за ефективністю функціонування організації [3, с. 11].

Проведений аналіз наявних наукових підходів до трактування змісту категорії 
«контроль» показав, що поглядам притаманна одностайність думок у частині встановлення та ідентифікації методів контролю, які визначаються як сукупність прийомів, способів і дій, що допомагають у встановленні відповідності діяльності органів влади нормам і вимогам чинного нормативно-правового поля.

Також доцільно відмітити, що вчені, роботи яких присвячені процесу адміністрування й управління, серед різних видів контролю виділяють також аудит, бухгалтерський облік, ревізію, перевірки, моніторинг тощо [8, с. 21].

Підсумовуючи вищезазначене, можемо сказати, що метод контролю $€$ певною сукупністю прийомів і методів визначення відповідності діяльності організацій чинним нормам, правилам, завданням, дорученням.

Метод контролю, на відміну від функції контролю, характеризує не змістовноцільове призначення діяльності органу публічної влади, а лише спосіб забезпечення належного виконання прийнятих рішень [9, с. 68].

Науковці розрізняють види контролю за різними критеріями. За суб'єктами контроль поділяється на громадський, парламентський, адміністративний, судовий. Т. Наливайко розрізняє два види контролю в системі державно-суспільних відносин державний і громадський. Однією з ознак, за якими визначається тип державного режиму, $\epsilon$ аналіз співвідношення частки державного та громадського (публічного) контролю й характеру їх взаємовідносин $[10$, c. 10$]$.

За характером стосунків суб'єкта й об'єкта контроль може бути внутрішнім (відомчим) і зовнішнім (позавідомчим). Для внутрішнього контролю характерним $\epsilon$ функціонування суб'єкта й об'єкта контролю в одній площині, тобто в одній організації; щодо зовнішнього контролю, то для нього характерним є здійснення контролю відокремленим зовнішнім суб'єктом діяльності.

Фахівці в галузі державного управління виділяють функціональний, адміністративний і фінансовий контроль. Функціональний контроль пов'язаний з основною діяльністю організації, ії політикою, процедурами й методами; адміністратив- ний - включає процедури й документацію стосовно процесу прийняття рішень, а фінансовий контроль пов'язаний із процедурами ведення фінансової документації [11, с. 338].

За етапами проведення контроль поділяється на попередній, поточний і підсумковий. Попередній (превентивний) контроль $€$ передумовою ефективної поточної діяльності організації чи установи. Основним завданням цього виду контролю $\epsilon$ аналіз і визначення готовності установи до ведення своєї діяльності й виконання покладених на неї функцій. Ключовими напрямами здійснення перевірки $є$ якість управлінських рішень; робота з персоналом; фінансово-матеріальний стан і використання ресурсів.

Під поточним контролем розуміється контроль, який проводиться в ході діяльності установи чи організації. Цей вид контролю розподіляється на оперативний (за основними поточними видами діяльності) і стратегічний (визначає наступні етапи розвитку організації чи установи, оцінку рівні ефективності).

Крім того, визначають стратегічний контроль як збір та обробку інформації про реалізацію стратегії, порівняння й зіставлення іï з параметрами, що задані заздалегідь у стратегічних планах і програмах, виявлення відхилень, аналіз причин, що дали таке відхилення, їх оцінювання та прийняття рішення щодо корегувального впливу.

Наступним видом контролю $є$ підсумковий контроль, який пов'язаний із наданням ретроспективної оцінки результатів діяльності установи чи організації, висновки за якою можуть бути покладені та використані для подальшого планування.

Для вивчення контролю доцільно дослідити їх основні ознаки та характеристики, серед яких виділяються завдання, цілі, види, об'єкти проведення контролю тощо. Основною метою контролю $€$ підвищення ефективності виконання управлінських рішень та інших завдань.

Цілі контролю можна поділити на стратегічні й тактичні (або прикладні). Стратегічна мета контрольної діяльності полягає у створенні умов дотримання законодавчих і дисциплінарних суспільних норм і норм державного управління. Тактична 
ж мета контрольної діяльності розкривається в «спостереженні й аналізі відповідності діяльності всіх суб'єктів суспільних відносин установленим державою параметрам, а також у певному «корегуванні» відхилень від цих параметрів» [12, с. 21].

Завдання контролю $\epsilon$ загальними та конкретними. Конкретні завдання охоплюють тільки окрему сторону або вид діяльності (використання ресурсів, виконання бюджетних програм, достовірність відображення даних у фінансовій звітності тощо). Загальні завдання контролю охоплюють усі галузі діяльності об'єкта контролю.

Під об'єктом контролю розуміється організація або окремий аспект ії діяльності, що підлягає контролю. Суб'єкт контролю - органи державної влади та місцевого самоврядування, їх посадові особи, група людей або організація, що наділені відповідними повноваженнями. Предмет контролю - це стан або поведінка об'єкта управління. Це може бути діяльність органів чи їх структурних підрозділів у цілому (загальний контроль) або окремі аспекти діяльності, що характерно для проведення вибіркового контролю.

Підсумовуючи здобутки науковців, можемо зробити висновок, що нагляд $\epsilon$ окремою формою контролю, у ході реалізації якої після виявлення порушень застосовуються заходи впливу. Для контролю, на думку практиків, характерними $\epsilon$ діяльність у межах чинного нормативноправового поля як самої організації, так й окремих органів і посадових осіб.

Контроль і нагляд досить часто трактують як тотожні поняття, зважаючи на їх єдину мету (забезпечення законності, поновлення порушених протиправним діянням правовідносин, притягнення винних до юридичної відповідальності), можливість їх здійснення в однакових формах (перевірки, вимоги звітів, пояснень тощо).

Разом із тим варто відзначити, що контроль відрізняється від нагляду. Контрольна діяльність може застосовувати такі методи, як скасування акта перевірки, так і відмова схвалення акта. Для нагляду характерним $€$ лише наступний контроль за наявності підстав зупинення дії акта з вимогами усунення порушень закону, а в разі відмови - звернення до суду з позовом про скасування відповідного акта. Ще однією відмінністю нагляду від контролю $\epsilon$ можливість контролюючого органу втручання в поточну діяльність об'єкта контролю та можливість застосування заходів впливу [7, с. 432].

Повертаючись до попередньо зроблених висновків, зазначимо, що контроль, відповідно до його основного трактування, може включати лише першу стадію (інформаційну) та оцінювальну, оскільки контроль не передбачає накладання окремих санкцій як самостійних заходів [13, с. 198]. Контрольні заходи повертають управління об'єктом до встановлених моделей і норм функціонування, тобто вже виконують корегувальну функцію $[14$, с. 23].

Визначення сутності контролю у сфері місцевого самоврядування вимагає його аналізу в різних аспектах: як функції державних органів, форми реалізації владних повноважень органами держави та сукупності прийомів і способів, що можуть бути застосовані в процесі контрольної діяльності.

Критерії розмежування підходів до визначення різних аспектів контролю вказує С. Серьогіна, зазначаючи, що функція контролю свідчить про змістово-цільове призначення діяльності самого органу публічної влади. При цьому метод контролю визначає порядок виконання рішень $[9$, c. 68].

Контроль $€$ об'єктивним соціальним явищем, ефективна його організація та застосування у сфері місцевого самоврядування $\epsilon$ вкрай необхідним, без цього неможливо сподіватися на подальший розвиток цього інституту. Наглядові функції завжди здійснюються стосовно непідпорядкованих органів державного управління, інших об'єктів. У системі публічної влади окремі органи інколи називають органами нагляду (органи пожежного, пробірного або іншого нагляду), а фактично вони $є$ органами державного контролю. Семантичне значення понять «контроль» і «нагляд» $\epsilon$ тотожним і визначається як перелік дій спостережного характеру, метою яких $\epsilon$ перевірка відповідності будь-кого (або -чого) відповідним правилам. Спільним для цих понять також $є$ мета, така як 
забезпечення дотримання законодавчих і дисциплінарних норм. Форми здійснення обох понять $\epsilon$ подібними. Контроль у найбільш загальному значенні являє собою певну діяльність, що полягає в перевірці, спостереженні, звірці [3, с. 93].

Висновки. Виходячи з викладеного, поняття контролю можна трактувати як комплекси заходів спостережного характеру, спрямованого на відповідний об'єкт контролю, з метою отримання достовірних і повних даних про стан об'єкта; застосування заходів запобіжного характеру; надання рекомендацій щодо відновлення нормального функціонування об'єкта контролю; ідентифікації умов і ризиків порушення законодавства; заходи притягнення до відповідальності.

3 погляду ж теорії створюється основа для розкриття взаємозв'язку контролю
3 іншими засобами забезпечення законності й дисципліни, зокрема виявлення спільних і відмінних рис із наглядом. Необхідність належного правового врегулювання контрольної діяльності, оновлення нормативної бази та розв'язання багатьох практичних недоліків $\epsilon$ сьогодні очевидною та назрілою потребою. Водночас, на наш погляд, вони не $є$ достатнім підґрунтям для виділення контрольної галузі права.

Отже, підсумовуючи все вищезазначене, варто зауважити, що контроль - явище соціальне, багатопланове, яке з позицій переважно філософських і нормотворчих, визначається через сукупність дій і заходів, здійснюваних з метою спостереження за діями фізичних і юридичних осіб або для встановлення будь-яких явищ, фактів при дослідженні об'єктів матеріального світу.

\section{ЛITEPATУРA:}

1. Данильян О.Г. Місце і значення соціального контролю у сфері правового виховання. Проблеми законності. 2009. № 103. С. 220-225.

2. Косінов С. Контроль над публічною владою: теоретико-правова характеристика. Вісник Національної академії правових наук України : збірник наук. праць. Харків : Право, 2013. № 4 (75). С. 49-57.

3. Косінов С.А. Контроль у демократичній державі : монографія. Харків : Право, 2015. 360 с.

4. Косінов С. Контроль над публічною владою: теоретико-правова характеристика. Вісник Національної академії правових наук України : збірник наук. праць. Харків : Право, 2013. № 4 (75). С. 49-57.

5. Афанасьев В.Г. Научное управление обществом: Опыт системного исследования. 2-е изд. Москва : Политиздат, 1973. 392 с

6. Административное право Украины : учебник / под общ. ред. Ю.П. Битяка, В.Н. Гаращука, В.В. Зуй. 2-е изд. Москва : Право, 2012. 656 с

7. Правовая система Украины: история, состояние и перспективы : в 5 т. Харьков : Право, 2011, Т. 2 : Конституционные основы правовой системы Украины и проблемы ее совершенствования / под общ. ред. Ю.П. Битяка. 632 с.

8. Коломоєць Т. Методи контролю за діяльністю органів місцевого самоврядування України при реалізації ними повноважень у сфері публічного управління: пошук оптимального варіанту. Юридична Україна. 2012. № 4. С. 20-24.

9. Державне будівництво і місцеве самоврядування в Україні : підручник / за ред. С.Г. Серьогіної. Харків : Право, 2013. 360 с.

10. Наливайко Т.В. Громадський контроль в Україні як інститут громадянського суспільства: теоретико-правовий аспект : автореф. дис. ... канд. юрид. наук : 12.00.01. Львів, 2010. 18 c.

11. Енциклопедичний словник з державного управління / за ред. Ю.В. Ковбасюка. Київ : НАДУ, 2010. $820 \mathrm{c}$.

12. Андрійко О.Ф. Організаційно-правові проблеми державного контролю у сфері виконавчої влади : дис. ... докт. юрид. наук : 12.00.07. Київ, 1999. 390 с.

13. Хріпливець Д.Є. Удосконалення системи відповідальності органів і посадових осіб місцевого самоврядування. Теорія та практика державного управління. 2010. Вип. 4. С. 179-184.

14. Горшенев В.М. Контроль как правовая форма деятельности. Москва : Юрид. лит., 1987. 176 c. 